\title{
Intergroup Rhabdomyosarcoma Group IIIb
}

National Cancer Institute

\section{Source}

National Cancer Institute. Intergroup Rhabdomyosarcoma Group IIIb. NCI Thesaurus.

Code C148021.

Localized or regional disease; resection (debulking of more than $50 \%$ of tumor). 